\title{
and Health (ICASSETH 2019) The Legal Study of the Compulsory Immunization Program to Comply with Children's Right to Health
}

\author{
Any Fitriyani, Endang Sutrisno*, Waluyadi Waluyadi \\ Universitas Swadaya Gunung Jati \\ Cirebon, Indonesia \\ *endangsutrisno94@gmail.com
}

\begin{abstract}
The Compulsory Immunization Program for children is a form of government obligation in the health sector. It is very important considering the development process must be supported by healthy human resources. The realization of this public policy was built through Law No 36 of 2009 on Health and the Regulation of Health Ministry No12 of 2017 on the Implementation of Compulsory Immunization. This regulation is faced with the aspects of legal awareness and legal compliance of citizens who do not fully understand the importance of Compulsory Immunization Program. The objective is to examine the legal awareness and legal compliance of the community towards the fulfillment of children's rights through compulsory immunization programs. The method used in this study is normative juridical. Research findings indicate that compulsory immunization policies for the fulfillment of children's rights must involve the cooperation of the Regional Government and community participation. The response of stakeholders who make policies, namely the Regional Government through the public health center, must be able to act appropriately and quickly in terms of handling this policy This description can be irony when immunization is understood as fulfilling children's rights. children have the right to health as the most fundamental right. Legal norms have mandated that goal.
\end{abstract}

Keywords: compulsory immunization program, children's rights, health

\section{INTRODUCTION}

Health is the initial capital of human beings to do all their activities and is an indicator of the level of their prosperity, so that every human will do various efforts in order to get a healthy life. Article 1 Point 11 of Law No 36 of 2009 on Health states that: health effort is every activity and/or set of activities carried out in an integrated and continuous way to maintain and improve the degree of public health in the form of disease prevention, health improvement, treatment illness and recovery by the government and/or community.

Currently the development of the health sector in Indonesia has a double burden such as infectious diseases and degenerative diseases. The eradication of infectious diseases is very difficult because it can spread in many areas. The compulsory immunization program is an effort to prevent infectious diseases, set out in Law No 36 of 2009 on Health. A compulsory immunization program is a policy. Public policy is the strategic use of available resources to solve public or government problems. Public policy is a form of intervention carried out continuously by the government in the interests of disadvantaged groups in society so that they can live, and participate in broad development.

Legal norms come in private sphere. It is as the argument that the law does not work in a vacuum. For this reason, social problems must be handled extraordinarily by law and must work in an extraordinary way [1]. Law enforcement refers to implementing the textual of legal norms in the social realities of society. The content of the substance of the norm is hoped to be clarified through legal behavior so that questions about legal awareness, legal compliance, legal feelings, and legal attitude will be more prominent [2]

Immunization is an attempt to actively raise/increase a person's immunity against a disease, so that if one day a person is attacked with the disease s/he will not be sick or will be mild illness. Normatively the legal order has regulated in Law No. 36 of 2009 on Health, as stipulated in Article 130 paragraphs and Article 132 paragraphs (3) and (4).

Law No. 36 of 2009, Article 130 explained that the Government is obliged to provide complete immunizations to every baby and child. And Article 132 (3) regulates that every child has the right to obtain basic immunization in accordance with applicable regulations to prevent the occurrence of diseases that can be avoided through immunization. Paragraph (4) as further provisions on types of basic immunizations as referred to in Paragraph (3) is stipulated by Ministerial Regulation. Furthermore, the Ministerial Regulation in this case is the Minister of Health Regulation No. 12 of 2017 on the Implementation of Compulsory Immunization. The study questions on how the legal basis used to implement the compulsory immunization program related to the fulfillment of the child's right to have healthy life. This is important in the macro level to build a better quality of public health in the future for a better generation.

In carrying out its functions in community life, the law must be supported by effective application, both in its position as a social controller for citizens and as a change patterns of life, behavior, and action or creating the pattern of life needed by the law, including cultural pattern. As the function to control community, law has a role to maintain the community so that they obey the law, not break it. If the community obeys the law, the role of law as a controller has been achieved. On the contrary, If the community break the law, the role of the 
law as a social controller hasn't been achieved. The law cannot run its function as social engineering when the community changes continuously as the result of the development process that has huge implication to the dynamics of community development [3]. In daily information, people can find out events and actions that can be categorized as violations of the law that cause victims or losses, both in individuals and in society. An interesting impression arises, as if irony has occurred because violations of the law occur in the midst of the process of community development [4]. The government must be able to give affirmation to the community, the law that is made leads to the interests of the community and oriented towards social justice [5]. Indonesia today is faced with a very "unique" problem of law performance regarding the formal truth treated as the most dominant consideration of legal decision embracing reined Rechtslehre Kelsenian's way of thinking, an approach that is still in further discussion through a more holistic alternative paradigm [6].

Building legal awareness is not easy because not everyone has awareness. Law as a social phenomenon is an institution and a social controller. The community need various institutions to meet their needs and facilitate the fulfillment of those needs. The community need the institutions as an understanding of legal awareness. Law is an important element in the development of politics and it makes the relationship with government policy clearer. Through legislation, the Government determines what it can do and what not to do. Law defined as legislation is a system of norms where the rule of law is arranged in unity within a hierarchical manner. The lower legal norms should not be contradictory to the higher legal norms [7].

In reality, compliance with the law is not the same as other social compliance, legal compliance is an obligation that must be carried out and if it is not implemented there will be sanctions. It is not the same as social compliance. If social compliance is not carried out, social sanctions will be given by community as the judgment. Legal compliance tends to be forced. For related efforts to realize an effective law system it is necessary to reorganize the legal institution, which is supported by qualified human resources and culture and a growing awareness of the community about law [8].

If we elaborate on the reasons why people do not obey the law, it happens due to diversity of culture in society. A person obeys the law because it is essentially religious or natural, therefore it can evoke justice. The moral obligation of the community is to obey the law, although the obligation is compelling. The practice of these obligations is not absolute. The diversity of cultures and living norms grow rapidly in society. The moral obligation is to solve the problems in certain condition.

\section{METHODS}

The research method used is normative juridical that emphasizes on the law as the norm described in the legal provisions, Law Number 36 Year 2009 on Health and Minister of Health Regulation Number 12 Year 2017 on Immunization. The rule of law is examined through research as a legal basis for completing the fulfillment of children's rights, so that the law can be used to activate the function of the degree of public health, especially children. In some cases, the application of these norms as a contradiction (das Sollen) has led to debate, for this reason the application of the law must be examined in the study with the support of primary legal materials, secondary legal materials with sufficient tertiary legal materials, to analyze the formulation of research problems. Synchronization and harmonization of regulations will be a measure of virtue in the translation of legal concepts as written norms.

\section{RESULTS AND DISCUSSION}

The existence of a city in Indonesia caused by the impact of development has required the city to fulfill the interests of people's development. The conflict of new values has affected the lives of the people. Confrontation of the traditional norms with modern norms results in reality at the intersection of norm encounters; communities lose their basis foundation to undergo the development process, while the modern norms are not fully accepted as guidance for the development process [9]. The description can happen in the implementation of policy in the Compulsory Immunization Program for children. The program is designed to fulfill children's rights but it always has to deal with issues of cultural values and religious norms. In its implementation, the officers must understand the cultures and religious values in that community before they implement this program. The factor of legal awareness and legal compliance becomes the most fundamental subject if the program is implemented to achieve the target.

The immunization activity program has been held in Indonesia since 1965, and is one of the preventative measures in spreading the disease to other regions. It has proven to be very cost effective. Immunization is a public health effort that aims to reduce the number of illness and death due to diseases, especially diseases that can be prevented by immunization, such as; Hepatitis B, Diphtheria Tuberculosis, Pertussis, Tetanus, Polio, Measles, Pneumonia and Meningitis. This Compulsory Immunization Program is one of the priority activities from the Ministry of Health of the Republic of Indonesia as a tangible evidence form of the Government's commitment to achieve the Millennium Development Goals (MDGs), to reduce mortality rate in children. It is also as the fulfillment of children's rights to get immunizations.

The results show that the implementation of the compulsory immunization program is commonly known as routine immunization activities at Health Center and schools without being charged. There are two types of immunizations that are carried out in these activities, namely:

- basic immunization is an immunizations given to babies;

- advanced immunization is immunization that aims to complete basic immunizations for babies. It will be given to toddlers and school-age children.

Immunization has several benefits for both children, parents and the state, such as: 
- The immunization gives babies and children immunity and protects them from diseases;

- The immunization avoids them from disability;

- For parents/family, the immunization eliminates anxiety and medical expenses if the child has contracted the disease;

- For the state and society, the immunization can improve the level of health, create a strong and intelligent state to continue the process of the development, and avoid loss generation; and

- It can reduce the rate of morbidity and mortality of babies and children

To achieve these national goals, the development effort is implemented. It is a series of development that is comprehensive, directed and integrated, such as the development in the health sector. Health is a human right and one of the elements of prosperity that must be realized in accordance with the ideals of the Indonesian people as referred to Pancasila and the Preamble of the 1945 Constitution of the Republic of Indonesia.

Therefore, every effort to improve the highest degree of public health is carried out based on the principle of justice or non-discriminatory, participatory, protection, and sustainability. It is very important to build Indonesian human resources, health and national competitiveness, and national development. The Compulsory Immunization Program is a form of government policy as an effort to improve the highest health status.

Other findings tell that the legal basis in the implementation of the Compulsory Immunization Program policy is regulated in legal norms, like:

- The 1945 Constitution of the Republic of Indonesia, Article $28 \mathrm{H}$, states that every person has the right to live in prosperous life physically and mentally, to stay, to have a good and healthy environment, and to have health services. Article 34 paragraph (3) states that the state is responsible for the provision of adequate health care facilities and public facilities. Fulfilling and realizing the rights for every citizen in getting proper health services is the government's obligation to provide quality health facilities as mandated by the 1945 Constitution of the Republic of Indonesia. Health Center is a public health service provider, so government intervention is needed.

- Law No 36 Year of 2009 on Health, Article 46 that an integrated and comprehensive health effort is carried out in the form of individual health efforts and public health efforts to realize the highest health status for the community. Article 47 stated that health efforts are held in form of activities with promote, preventive, curative, and rehabilitative approaches that are carried out in an integrated, comprehensive, and sustainable manner. Furthermore, the contents in Article 2 regulate disease prevention. It is in the form of efforts made by the government, regional government, and/or the community to avoid or reduce risks, problems, and adverse effects due to disease. And in substance Article 3, the Government and the Regional Government guarantee and provide facilities for the continuation of efforts to improve health and prevention.

Every person has equal right to obtain access in the field of health, to obtain safe, quality, efficient, and affordable health services in service facilities in caring out health service efforts, both preventive, curative and rehabilitative way done by the government, regional government and/or the community.

The government is responsible for the availability of all forms of quality, safe, efficient and affordable health efforts as well as the availability of the environment, order, and health facilities for both physical and social for the community to achieve the highest health status. The legal bases for fulfilling children's rights in obtaining immunizations are:

- Law Number 36 of 2009 on Health, regulated in Article 130 that the Government is obliged to provide complete immunization for every baby and child.

- Law Number 36 of 2009 on Health, the content of Article 132 Paragraph (3) regulates that every child has a right to receive basic immunization in accordance with applicable regulations to prevent diseases that can be avoided through immunization. And in Article 4 that further provisions on the types of basic immunizations as referred to in Paragraph (3) are stipulated by Ministerial Regulation.

- Regulations of the Minister of Health Number 12 of 2017 on the Implementation of Immunizations are Article 2, Article 3, Article 4, Article 5, Article 6, Article 7, Article 10, Article 12, Article 13, Article 21, Article 22, Article 24, Article 26, Article 27, Article 35, Article 36, Article 37 and Article 38.

The starting point for this issue goes from the commitment of the rules in a law state, that state activities should be based on law [10].

One of the Government's efforts in developing health sector and fulfilling the rights of Indonesian citizens to obtain access and services in the health sector is that the Government is obliged to provide immunizations for all children in Indonesia without exception. Immunization is a preventive activity or prevention efforts in the health sector.

\section{CONCLUSION}

The policy on the Compulsory Immunization Program for the fulfillment of children's right to health is very important to build public health, even though regulatory products have governed them through several laws and regulations, such as Law No. 36 of 2009 on Health and Minister of Health Regulation No. 12 of 2017 on Immunization. The regulation does not automatically apply effectively because it has to deal with aspects of legal awareness and legal compliance of citizens, the place where the law works. The dynamics of the operation of the law must be balanced with the process of socialization and legal counseling on target, with the effort to increase the human resources of health workers. 
Public policy formulated in the form of manifestation of legislation products is the main indicator of the Government and Regional Government's will in developing public health, especially to the compulsory immunization program for children, because the fulfillment of public health is the Government's obligation.

\section{REFERENCES}

[1] E. Sutrisno, "Implementasi Pengelolaan Sumberdaya Pesisir Berbasis Pengelolaan Wilayah Pesisir Secara Terpadu Untuk Kesejahteraan Nelayan”, Jurnal Dinamika Hukum, vol. 14, no. 1, p. 3, 2014.

[2] E. Sutrisno, "The Study Of River Pollution Related To Domestic Waste In The Perspective Of Community Legal Culture", South East Asia Journal Of Contemporary Business, Economics And Law, vol. 12, p. 134, 2017.

[3] E. Sutrisno, Bunga Rampai Hukum \& Globalisasi. Bogor: In Media, 2015 , p. .33
[4] E. Sutrisno, Rekonstruksi Budaya Hukum Masyarakat Nelayan Untuk Membangun Kesejahteraan Nelayan Studi Kritis Terhadap Pemaknaan Hukum. Yogyakarta: Genta Press, 2013, p. 97.

[5] E. Sutrisno, "Relations Between Legal Culture and Economic Empowerment among Marginalized Group of Farmers," Journal of Legal, Ethical and Regulatory Issues, vol. 22, no. 3, pp. 22-3-329, 2019.

[6] E. Sutrisno, "Tracing the Performance of Law in Indonesia (A Perspective of Thomas Kuhn's "Normal Science", Journal of Law, Policy and Globalization, International Institute for Science, Technology \& Education Accelerating Global Knowledge Creation and Sharing, vol. 37, p. 126, 2015

[7] E. Sutrisno and I. Jazilah, "The Licensing Policy for Groundwater Extraction and Management for Hospitality Industry in Cities in Developing Countries," Journal Water Policy, IWA Publishing, vol. 21, no. 3, pp. 1-10, 2019.

[8] E. Sutrisno, "the Legal Problem of Using Non Environmentally Friendly Fishing Gear in the Fisher Community of Indonesia," EurAsian Journal of BioSciences, vol. 13, no. 2, p. 2107, 2019.

[9] E. Sutrisno, The Local Governments Dilemma in Accommodating the National Regulation. Saarbrucken, Germany: Lambert Academic Publishing, 2015, p. 16.

[10] R. Yasin, "Telaah Putusan MK dalam Sengketa PHPU Pilpres 2004 (Perspektif Negara Demokrasi Konstitusional)," Jurnal Konstitusi, vol. 11, no. 4, 2014 